\title{
DEVELOPMENT TENDENCY OF RURAL TOURISM IN VARIOUS COUNTRIES IN THE WORLD AND COMPARATIVE STUDY
}

\author{
Yu Juntong \\ Postdoctoral Fellow, Chongqing Normal University \\ DOI: 10.46609/IJSSER.2021.v06i03.018 URL: https://doi.org/10.46609/IJSSER.2021.v06i03.018
}

\begin{abstract}
As the tourism industry is becoming increasingly popular, the psychology of current tourists is changing gradually. In traveling, people tend to pay more attention to the experience of mutual culture. Especially for the current rural tourism, it can provide people with a brand new experience, show strong regional characteristics, promote the current industrial restructuring and achieve sustainable development of the rural economy. On such basis, this paper analyzes the development trend of rural tourism in the world combining its actual development status, compares it, and clarifies the differences among different countries, so as to promote the development of rural tourism in the world, and cater to the development of the times.
\end{abstract}

Key Words: Various Countries in the World, Rural Tourism, Development Tendency, Comparative Research.

\section{Rural Tourism Development Tendency in Various Countries in the World}

At the present stage, affected by the geographic area factors, the rural tourism development in various countries in the world presents different tendencies. Their patterns and contents are also diversified. By reading a large amount of literature, the author utilizes the literature review method and on-site investigation method and so on to summarize the status and tendency of the rural tourism development in representative countries in the world.

\subsection{Cognition of Rural Tourism Development in Developed Countries such as Europe and America}

\subsubsection{Rural Tourism Development in "Britain"}

Rural tourism is an important constituent part of the British tourism industry. It began in the 1970s and was gradually transformed from "returning to the home village to visit the family 


\section{International Journal of Social Science and Economic Research}

ISSN: $2455-8834$

Volume:06, Issue:03 "March 2021"

relatives" by the people of the middle and high levels into "village guesthouse" and then into "farmland vacation". The British government has given high attention and support to the development of the rural tourism industry. Under the support of a series of policies and funds (including vocational education, industrial management advice, capital investment, market guidance, etc.), the rural tourism infrastructure in Britain is improved continuously and there tend to have more rural tourism projects. In addition to the traditional village guesthouse, projects such as free camping and long-term farm lease of farmland are emerging, attracting domestic and foreign tourists to visit the rural natural landscape and promote the optimization and development of rural tourism.

\subsubsection{Rural Tourism Development in "France"}

Because of the good agricultural foundation, the rural tourism in France started earlier and its rural tourism development level is stronger than other countries. As early as 1950, the French government provided policy support for the development of the rural tourism industry. By 1980, a relatively complete pattern of diversified rural tourism industry had been formed. At present, French rural tourism is an important source of French national economic growth and anessential part of the daily life of local people. The good agricultural foundation in France allows local people to have relatively large farms. People produce products with their own characteristics according to their own practical conditions and demands, such as "farm inn" and "farm camping" to provide quality services to visitors. Tourists can perceive the ecology beauty, folkway beauty and culture beauty in various rural tourism activities, such as "play golf", "go sightseeing on boat", "horsemanship training", "farm cate" and so on.

The development rules and characteristics of rural tourism in France can be summarized as follows: Firstly, in the rural tourism development process, France pays attention to government guidance and support. On the one hand, the government controls the development of rural tourism industry with legal approaches, requiring rural tourism operators to provide corresponding protection measures for tourists. Meanwhile, the government provides capital and policy supporton village housing, rural tourism operator education and agricultural marketing sales. For example, the government encourages farmers to develop characteristic country house hotels through providing subsidies and bank loans and so on, and the Joint Tourism Commission provides education and training services for rural tourism operators. On the other hand, it pays attention to the protection of the historical and cultural characteristics of the countryside, with an expectation of enhancing the cultural connotation of rural tourism. Secondly, in the rural tourism development process, France follows the opinions of the people and conducts tourism product development and design in the "Government + Industry Association + Farmers" operation model. Thirdly, in developing and designing rural tourism products in France, attention is given 


\section{International Journal of Social Science and Economic Research}

ISSN: $2455-8834$

Volume:06, Issue:03 "March 2021"

to the shaping of the brand image of tourism products. It enhances product quality, promotes the cognition and satisfaction of the tourists to the tourism products through the implementation of the product certification system.

\subsubsection{Rural Tourism Development in "the US"}

The vast territory of the United States, perfect road network, high-quality national park system and high living standard of the people have laid a good foundation for the development of rural tourism in the United States. At present, rural tourism in the United States has become an indispensable part of the US tourism industry system, and it has important influences on promoting the economic recovery of the US rural economy and strengthening the regional construction of the United States. The American rural tourism project has a variety of characteristics, and the experience of tourism products is relatively strong. Visitors can enjoy the happiness of rural life by participating in village concert, free picking of fruits and vegetables, fishing competition and so on. At the same time, the Shengjiekebu Town in the US has attracted tourists to visit with its perfect tourism supporting measures, public infrastructure, long-standing historical culture, traditional folk custom and folk handicraft culture.

The development rules and characteristics of rural tourism in United States can be summarized as follows: Firstly, governments at all levels in the United States pay very high attention to the allocation and utilization of regional resources in the rural tourism development process. In developing and designing the product project, the local resources are taken as the core to carry out market positioning, and the corresponding products are developed with the demands of the tourists being fully considered, so as to achieve sustainable development of the rural tourism industry. Secondly, because of the relatively high awareness of environmental protection in the United States, NPS (National Park Service) uses VERP (Visitor Experience and Resource Protection) technology to coordinate tourism product development and resource conservation in developing the rural tourism industry, which is not only conducive to enhancing the tourist experience of tourists, but also has a positive impact on promoting the stable development of the tourism industry. Thirdly, the US government provides a series of policy support for rural tourism, such as the "Village Tourism Loan Program" and the "Governmental Promotion of Rural Tourism" and so on. Fourthly, the non-governmental organizations and the American people have a high degree of participation in the development of rural tourism, forming a volunteer organization for rural tourism construction and management, so as to promote a better and faster development of rural tourism in the United States.

\subsection{Cognition of Rural Tourism Development in Asian Countries}


International Journal of Social Science and Economic Research

ISSN: 2455-8834

Volume:06, Issue:03 "March 2021"

\subsubsection{Rural Tourism Development in "Japan"}

Affected by factors such as the agricultural acreage, vacation system, and housing structure and so on, it is unable to organize large-scale farms and stationed tourism in Japan just as in Europe and the United States. However, due to the beautiful natural beauty, special folk culture and local specialties in Japan, the short-term rural tourism activities in leisure and entertainment mode is organized with "green tourism" as the core and relying on the forest resources, stream and river resources, pasture resources, folk culture resources and so on in Japan in developing rural tourism, so as to realize the integrated development of "village, agriculture and forestry, tourism" and other industries, promote the growth of regional economy. Among the Japanese rural European products, leisure farm is a kind of relatively outstanding rural tourism product, which has a relatively complete infrastructure, providing a good living environment for tourists. In the meanwhile, the scientific planning of landscape areas, flower and fruit areas, and forest areas provide visitors with different types and levels of experiential tourism activities, effectively enhancing the recognition and satisfaction of tourists on tourism products. For example, in the grape park, tourists can experience the pleasure of picking and tasting grapes in doing sightseeing. They can also participate in photography and sketching activities according to their practical needs.

The development rules and characteristics of rural tourism in Japan can be summarized as follows: Firstly, the Japanese government has given vigorous support to the rural tourism. For example, Japan introduced the "Rural Vacation Rule" in 1995 for rural leisure vacations, which put forward requirements for rural infrastructure construction. With the development of rural tourism, Japan has successively issued "related laws on promoting the utilization of agriculture, forestry and fisheries industries", the Forest Law and so on to provide legal protection for the development of rural tourism. At the same time, the Japanese government has intervened in rural tourism supervision and publicity to promote the standardized development of the rural tourism industry. Secondly, in the rural tourism development process, Japan takes the peasant family as the core, pays attention to the communication and exchange between urban and rural areas, promotes the autonomous participation of the Japanese nation in rural tourism construction, and forms the "urban and agriculture exchange activation organization" to guide and lead rural tourism operators to develop and design tourism products. Thirdly, Japan pays attention to individual household development in rural tourism. It starts sightseeing plantation, village restaurant, village guesthouse and other rural tourism activities, in which, the proportion of the individual household is relatively high. According to the statistics data of Japanese Ministry of 


\section{International Journal of Social Science and Economic Research}

ISSN: $2455-8834$

Volume:06, Issue:03 "March 2021"

Agriculture, Forestry and Fishery, the number of rural tourism operators in Japan had already exceeded 12000 in 2014, in which, the individual guesthouse accounted for a large proportion.

\subsubsection{Rural Tourism Development in "Thailand"}

As a world-famous tourist destination, Thailand has a great variety of tourism projects and its tourism service quality is relatively high. Kangchanabuli Province is a famous rural tourist destination in Thailand. Its unique natural landscape and historical culture have gave tourists deep impressions. With the cooperation of the Tourism Bureau, the Royal Forest Bureau and the rural cooperatives, Thailand rural tourism has formed a characteristic ecological tourism system. Under the leadership of the Ecological Tourism Cooperative, visitors can enjoy adventure, souvenir production, natural museum visiting, sightseeing on elephants and other experiencebased tourism services. Due to the corporate legal characteristics of the Kangchanaburi Ecotourism Cooperative, it has a relatively wide financing channel in the process of rural tourism construction, which is conducive to promoting the optimal development of the tourism industry and the regional economy.

The development rules and characteristics of rural tourism in Thailand can be summarized as follows: Firstly, it adopts the management mechanism of "government + community + external expert". The government provides rather strong capital and policy supports, so that the comprehensive development capability of the Thailand is rather high. Secondly, the Ecological Tourism Cooperative is guaranteed of the benefits and provides capital support for the tourist product development and design of the rural tourism operators. Thirdly, it has a high degree of public participation and the public plays an active role in rural tourism supervision and control, so as to realize the control and avoidance of the negative impact of tourism product development and design.

\subsubsection{Rural Tourism Development in "Korea"}

The rural tourism development process in Korea mainly adopts the model of "government intervention + market cultivation". In the process of development, attention is given to the organic combination of agriculture and tourism, emphasizing the effective interaction and communication between urban and rural areas. Since 1984, Korea has carried out the development and design of rural tourism resorts, folk villages and other rural tourism products with the aim of promoting the development of rural areas and fishing villages. On such basis, the 


\section{International Journal of Social Science and Economic Research}

ISSN: $2455-8834$

Volume:06, Issue:03 "March 2021"

tourism project is developing with village as the unit, such as the "green village experience project", "traditional themed village project" and so on, and the human resource construction is enhanced to emphasize on the high participation of villagers in the rural tourism construction.

As a matter of fact, affected by the Korean government, in the development of its oriented tourism industry, it has fully played its active role in promoting tourism investment and consumption guidance, and promoted the coordinated development of current tourism products and supply and demand to meet the current development demand. For example, the Korean government makes full use of its own advantages to help localities actively develop cultural industries, build a good tourism industry, and enhance the economic benefits of the tourism industry in China's tourism festivals or international conventions and exhibitions. It has its own obvious characteristics, which are specifically reflected in the following aspects: Firstly, affected and guided by the local government, Korea rural tourism innovates actively and strengthens the expressiveness of the current new village movement itself, so as to drive the promotion of rural economy. Secondly, in the development process, the tourism economy in suburban areas has gradually increased, prompting the rapid development of its transportation industry, improving its infrastructure construction, and accelerating the enthusiasm of the new village movement. Thirdly, combined with the actual situation, Korea actively innovates the current public tourism projects and enhances the government's guiding role in the development of rural tourism economy.

\section{Comparative Analysis of Rural Tourism in Various Countries in the World}

\subsection{Product Structure and Category in the Reception Systems in Various Countries}

\subsubsection{Comparison of Accommodation Product}

Comparatively speaking, the category of the accommodation products in rural tourism in developed countries is more than that in developing countries, reflecting a more diversified culture and incorporating a large number of cultural and creative elements to meet current needs. Specifically, it is mainly reflected in the following aspects:

Firstly, cultural resort. The accommodation product of this category mainly has a strong modernity sense. It is mainly provided to the high-end rural tourists, even some business teams and conference participators.

Secondly, cultural hotel. The concept is mainly originated in European countries. It is aimed to provide accommodation with culture atmosphere for current business travelers. The living 


\section{International Journal of Social Science and Economic Research}

ISSN: $2455-8834$

Volume:06, Issue:03 "March 2021"

condition is good, but the price is high. At the same time, in order to meet the special requirements of the residents themselves, it is usually equipped with conference halls, restaurants and business facilities. For example, in the United States, its own cultural hotel is mainly positioned as the current exclusive tourism and business market. However, there are obvious differences in Korea, and its own consumers are mainly current cultural independent tourists.

Thirdly, creative guest house. Creative guest house usually has a rather strong creativity. Normally, attractive and reasonable price is the biggest feature. It is mainly in the format of a dwelling and has a rather long history. In normal circumstances, most people will reasonably transform their own dwellings to have strong characteristics, which can attract more tourists.

Fourthly, creative self-service village community. This category of accommodation is rather high-end, and it has the characteristics of fine decoration, complete equipment and reasonable creativity and so on. In addition, a large amount of creative articles are equipped. However, comparatively speaking, its price is high and it can meet the current needs.

\subsubsection{Sightseeing}

For the current rural tourism, affected by its own property, its own "tour" includes two aspects: one is the unique landscape of the current village, for example, various agroparks, wineries and local museums in the countryside, which have been developed into a large number of scenery in the development process. The other refers to the characteristic landscapes around the village. For example, the surrounding scenic spots provide tourists with good tourist attractions through scenic development, including scenic spots, natural scenic spots, historical sites and natural scenic spots and so on. During the sightseeing process, the current tourists are provided with good landscape architectures and rich viewing contents. In the development process, they bring a large number of customers and enhance the economic benefits.

Taking Thailand as an example, the central area of Thailand - Kangchanabuli Province has strong characteristics in rural tourism. During the tour, tourists can actively visit the national parks, folk customs and natural museums and other related tourist attractions, as well as elephant protection village, Thai herbal medicine museum and agricultural product market with strong regional characteristics, promoting the tourists to have a better understanding in the sightseeing process.

\subsubsection{Characteristic Catering Product}

As to the current characteristic catering industry, affected by its own property, rural tourism in each country has its own strong regional characteristics and is associated with accommodation to meet current needs. In the meanwhile, in the catering industry development process in various 


\section{International Journal of Social Science and Economic Research}

ISSN: $2455-8834$

Volume:06, Issue:03 "March 2021"

countries, it also pays attention to the innovation of its own delicacy, designs actively and regards the present delicacy preparation, exhibition and tasting as the theme to enrich the tourist project.

\subsubsection{Shopping and Recreational Activity}

Affected by the property of rural tourism, the main products purchased by tourists in tourism are the characteristic agricultural and sideline products or handicrafts of the village. Such a phenomenon is true in all countries, and there is no obvious difference. For example, according to relevant data, shopping in current rural tourism has become one of the favorite activities of current tourists.

Recreation is the key content of current rural tourism. Affected by its own property, different from the traditional tourism, rural tourism itself pays more attention to experience, for example, experiencing rural life, rural culture, rural recreation and so on. In terms of extensive meaning, the starting point of rural tourism is to provide different living environments and experiences to the current tourists, which is quite different from urban life and has a strong leisure property.

Taking Thailand as an example, in the central area - Kangchanabuli Province, its entertainment activities in the rural area are quite diversified: the National Park, Agriculture Park, driving in mountainous areas, experience of riding an elephant, delicacy tasting and air gliding and so on, so as to provide tourists with rich experiences. The below table displays the rural tourism activities in various countries.

Table 1: rural tourism activities in various countries

\begin{tabular}{|c|l|}
\hline Category & \multicolumn{1}{|c|}{ Specific item } \\
\hline $\begin{array}{c}\text { Tourism } \\
\text { type }\end{array}$ & $\begin{array}{l}\text { Hiking, horseback riding, elephant riding, caravans, motorcycles, } \\
\text { trailers, long-distance bicycles, etc. }\end{array}$ \\
\hline $\begin{array}{c}\text { Water } \\
\text { activities }\end{array}$ & $\begin{array}{l}\text { Water fishing, swimming, boating, rafting, surfing, speedboat } \\
\text { experience, wetland activities, etc. }\end{array}$ \\
\hline $\begin{array}{c}\text { Air } \\
\text { activities }\end{array}$ & Light aircraft, gliding experience, hot air balloon, etc. \\
\hline $\begin{array}{c}\text { Physical } \\
\text { exercises }\end{array}$ & $\begin{array}{l}\text { Cave adventure, rock climbing, alpine skiing, hunting, tennis, golf, } \\
\text { etc. }\end{array}$ \\
\hline $\begin{array}{c}\text { Archaeology, visiting historical and cultural relics, appreciation of } \\
\text { rural folk songs, participation in country concerts, folk culture } \\
\text { festivals, learning folk heritages, handicrafts, visiting industrial and } \\
\text { agricultural, handicraft enterprises, museums and folk art studios, } \\
\text { searching for food sources, tasting local flavors, English training, }\end{array}$ \\
\hline
\end{tabular}


International Journal of Social Science and Economic Research

ISSN: 2455-8834

Volume:06, Issue:03 "March 2021"

\begin{tabular}{|c|l|}
\hline & gardening training, cooking training, dance training, etc. \\
\hline $\begin{array}{c}\text { Fitness } \\
\text { activities }\end{array}$ & Fitness training, spa service, fitness hall or massage and so on. \\
\hline $\begin{array}{c}\text { Recreationa } \\
\text { lactivities }\end{array}$ & $\begin{array}{l}\text { Country vacation, entertainment, observation of wildlife, church } \\
\text { pray, sketching, photography, leisurebar, etc. }\end{array}$ \\
\hline $\begin{array}{c}\text { Farming } \\
\text { activities }\end{array}$ & $\begin{array}{l}\text { Sowing, milking, grazing, brewing, fishing, orchard picking, } \\
\text { harvesting, processing of agricultural products, etc. }\end{array}$ \\
\hline $\begin{array}{c}\text { Themed } \\
\text { agricultural } \\
\text { activities }\end{array}$ & $\begin{array}{l}\text { Various themed agricultural activities, such as the National } \\
\text { Strawberry Festival, the Field Festival, the Wine Festival, the Apple } \\
\text { Festival, the farmer's life journey, etc. }\end{array}$ \\
\hline $\begin{array}{c}\text { Activities } \\
\text { for children }\end{array}$ & Self-made toys, pet breeding, kite flying and other related activities \\
\hline
\end{tabular}

*Data source: Wang Ruihua et al, An Initial Exploration of Overseas Rural Tourism Development Mode, Yunnan Geographical Environment Research, March, 2005.

\subsection{Consumption Model of Rural Tourists}

According to relevant data, it is found through survey that more than $85 \%$ of the current tourists are mainly engaged in their own leisure activities in order to meet their actual needs in the traveling process. They differ greatly in choosing the way of play, such as: husband and wife, family travel, single travel, travel with friends and group tour and so on. At the same time, their actual consumption preferences are quite different. For example, the figure below shows the number of favorite activities of American rural tourists in the survey year, as shown in Figure 1. 


\section{International Journal of Social Science and Economic Research}

ISSN: $2455-8834$

Volume:06, Issue:03 "March 2021"

Activity

Go out for dinner

Shopping

Play near the sand beach, lake and river

Visit historical site

Fishing

Hunting and boating Attend festivals and exhibitions

Ride bike or climb mountain

Religious rites

Camping

Sports

Visit a brewing plant or work on a farm Gambling

Visit local community

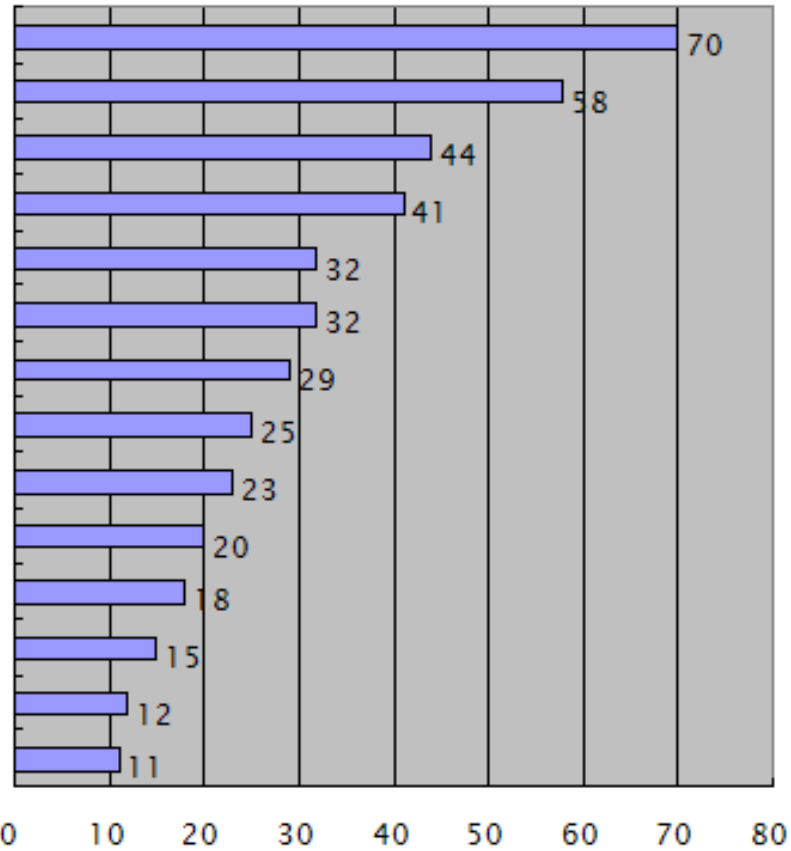

Percentage

Figure 1: Activities Preferred by American Rural Tourists

In fact, in the process of accommodation selection, people tend to have different choices according to their actual situation. For example, the following figure is the survey data of a rural tourism accommodation in the United States, as shown in Figure 2.

Accommodation

High-level abartment

Tent, mobile house or motor home

House of the friend or relative

Restaurant or motel

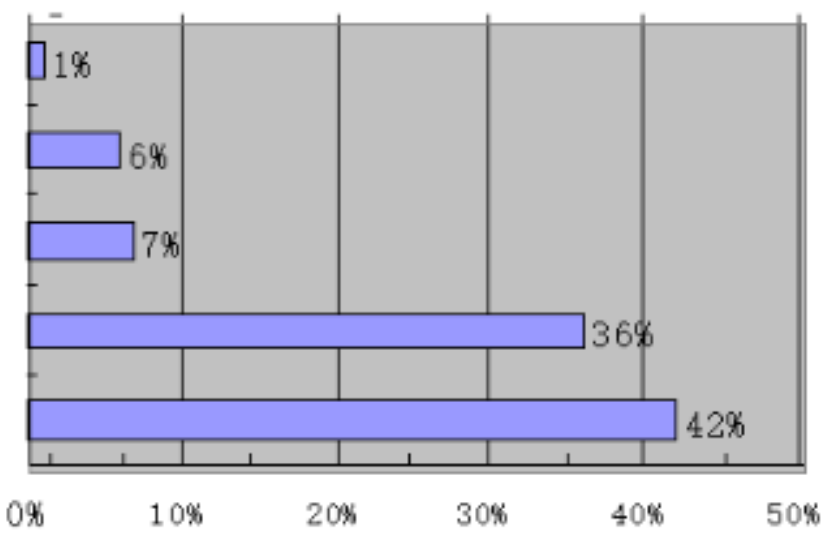

Percentage

*Data source: American Travel Industry Association ${ }^{1}$ (2001) 
International Journal of Social Science and Economic Research

ISSN: 2455-8834

Volume:06, Issue:03 "March 2021"

\subsection{Position and Role of Rural Residents}

For the current rural tourism in various countries, it forms a relatively complete model of "farmers + government + associations" combined with its own practical conditions in the development process. Farmers provide accommodation for tourists, but agriculture is still their principal industry, with the tourism industry being developed as a subsidiary industry,so that they can have more income. Due to its own property, the tourism subject is not an enterprise and the tourism development is lack of enough management. Therefore, rural residents themselves play a positive role in promoting. For example, the Regional Tourism Committee in Britain gives suggestions to farmers actively to promote the prosperity of tourism.

\subsection{Promotion Policy and Management Behavior of the Government}

In the process of tourism development, governments of various countries have taken active and effective measures to innovate in order to promote the current rural tourism economy:

The British government has actively introduced relevant policies actively, increased its financial input, and strengthened the construction of tourism infrastructure through capital investment, with an expectation of meeting the current needs. At the same time, it actively promotes the innovation of fishery and agricultural industries, and combines its own characteristics to develop tourist attractions. Especially for the current farm owners, it increases capital investment, improves the pastoral landscape, and promotes the comprehensive development of rural tourism.

In France, in order to stimulate the market development, the government holds a "Welcome to the Farm" Expo every year to provide tourists with good rural tourism information, so as to attract a large number of tourists to participate in tourism, and implements activities of guaranteeing the tourism quality. Moreover, it increases the capital support strength to lay a good foundation for the development of rural tourism. For example, a rural tourism association in France actively supports current hotel owners and actively cooperates with relevant departments to strengthen their own standards, in order to meet current needs.

In the United States, a common cooperation framework of the regional cooperation and development tourist industry has been formed with Fish and Wild Animal Management Bureau, Land Management Bureau, National Forest Park, Ministry of National Defense, Forest Park Center, American Tourism Management Bureau as the basis, so as to promote the development of the tourism industry.

In the tourism development process in Japan, the Japanese government itself plays an active 


\section{International Journal of Social Science and Economic Research}

ISSN: $2455-8834$

Volume:06, Issue:03 "March 2021"

facilitation role. For example, it actively formulates the perfect rural tourism development plans to promote the standard rural tourism development, strengthens the current infrastructure construction to provide perfect technical support, and increases the promotion of rural tourism. At the same time, Japan actively introduces relevant policies to lay a good foundation for the development of tourism. The Forest Law and Tourist Accommodation Law and so on are quite common.

In the tourism development process, Thailand actively promotes the present agriculture to cooperate with the tourism bureau, and establishes the standard ecological tourism cooperative on such basis, sets up the mechanism of integrated external experts, government and community, so as to give full play to the external role, thus laying a good foundation for the tourism development. For instance, it is actually manifested that Royal Forest Bureau allows to establish cooperatives in various provinces, carry out tourism activities actively and increase governmental support.

Now, in Korea, the capital and policy support of the government is rather strong in the development process, and the management process is rather strict, such as the common tourist park application, evaluation report, agriculture park development test and so on.The unqualified tourist sites are ordered to be rectified in a certain period, so as to promote the tourism development.

\section{Analysis of the Similarities and Differences in the Development of Rural Tourism in Different Countries in the World}

As a matter of fact, for the current rural tourism, although there are obvious differences in contents and forms among different countries due to their geographical factors, there are some similarities in their backgrounds. Through analysis, it can be found that the reasons are mainly reflected in two aspects: On the one hand, the acceleration of the urbanization process has prompted the rapid development of the current modernization, leading to the psychological improvement of people's pursuit of nature and the enjoyment of natural life. On the other hand, the industrialization speed is accelerating, prompting the gradual marginalization of the current agriculture. In order to upgrade the current agricultural economy and increase farmers' income, governments of all countries are innovating actively to strengthen tourism development, construct perfect industrial standard and promote the prosperous rural tourism in the optimization process. (Zhu Hua 2009).

At the present stage, the rural tourism in various countries gradually displays three similar characteristics: 
International Journal of Social Science and Economic Research

ISSN: 2455-8834

Volume:06, Issue:03 "March 2021"

-Rather appropriate planning and standard management,

-Accelerated communitization and emphasis on innovative development,

-Enact perfect policy and promote market improvement.

Meanwhile, the government actively promotes the rural tourism development, emphasizes on the authenticity of cultural environment and chooses the diversified development.

references

【1】Abraham Pizam. \&Yoel Mansfeld.(2005).Travel Consumer Behavior.Northeast University of Finance and Economics Press.

【2】A・V・Seaton. (1995).Tourism-The state of the art .London: John, WilleyLtd, 5(13),57-62

【3】AShley C.(2001).MaxwellS.Rethinkingrural development.Development policy review,19(4),395- 425.

【4】BrohmanJ.(1996).NewDirections in Tourism for Third WorldDevelopment.Annals of Tourism Research,23(1),48-56.

【5】C.D.Cooper and A.(1994).Lockwood.Progress in Tourism.Recreationand Hospitality Mangement .John Wiley\&Sons Ltd New Yory,4,56-57.

【6】Dvie 1.(1999).Taming the City inmo an An Gallary(R )tinpublished Pine B.J.,Gilmore J.H.The Experience Eeonomy .Harvard University Press,5,19-29.

【7】Gonzlez P A.(2017).Heritage and rural gentrificationin Spain: the case of Santiago Millas.International Journal of Heritage Studies,23(2), 125-140.

【8】Gomezelj D O.(2016).A systematic review of research on innovation in hospitalityand tourism .International Journal of Contemporary HospitalityManagement,28( 3 ),516-558. 
International Journal of Social Science and Economic Research

ISSN: 2455-8834

Volume:06, Issue:03 "March 2021"

【9】Hashemi N. \& Ghaffary G.(2017).A Proposed SustainableRural Development Index (SRDI): Lessons from Hajij vil-lage,Iran.Tourism Management,15(59),130-138.

【10】I Ling.(1990).MultiplierEffectsin Economies with Missing Risk Market.Journal of Economics,52(1),55-70.

【11】211Kes F,Panc G.\& Panj H,et al.(2011).The MultiplierEffect of the Development of Forest Park Tourism on Employment Creation in China.Journal of Employment Counseling,48(3),136144.

【12】Landry.C. \& Gnedosky M.(1997).Stuategy for Survival:CanCulture be an Engine for St Petersburg Revitalisation(M].Uopulished Dicusion Paper.

【13】Liu XiangMing. \& Yang Zhimin.(2002).Some Reflections on Chinese "Theaid The Poor program by tourism".EconomicGeography,(02),241-244.

【14】Liu Yi. \& Chen Lie,.(2004).A Study on Tourism-EliminationPoverty Programand its Development Model.Tropical Geography ,24(4),396-401

【15】Mölders. \& Tanja.(2014).MultifunctionalAgricultural Policies: Pathways towards Sustainable Rural Development.Inter-national Journal of Sociology of Agriculture \& Food,12(2),97-114.

【16】Ondry C.(2008).The Creative City:ATodlkitFor Urhan Inmuwations .Farthecan Publications Ld,2008.

【17】Reggers Rabowski S. \&WearingS L,et al. (2016).Exploring outcomes of community-based tourism on the KokodaTrack,Papua New Guinea: a longitudinalstudy of Participatory Rural Appraisal techniques.Journal of SustainableTourism,36(8/9),1-17.

【18】Richands G.C.(2000).Creative Tourism.ATLAS News,12(23),16-20

【19】Richards. G.(2005).Creativity:ANew Strategic Resource for Tourism.Intemational oumal of 
Cultural Poli.cy,25(9),32-43.

【20】Robert• G• heady.(1994).“ The common poor” problem in Tourism Landscapes. Annals of Tourism Resarch,16(3),596-611.

【21】Sharpley Richard.(2003).Rural Tourism and SustainabilityA Critique.New Directions in Rural Tourism,56(4),37-42.

【22】Sofield T., Bauer J. \& De LacyT,et al.(2004).SustainableTourism- eliminatingPoverty(STEP):An Overview.Gold Coast:CRC for Sustainable Tourism Pty Ltd.,18(4),15-19.

【23】212Scheyvens R. \& Momsen J H.(2008).Tourism and Poverty Reduction:Issuesfor Small Island States.Tourism Geographies,10(1),22- 41.

【24】Steven Salen on.(2004).Tourism, a tool for poverty alleviation?.Masterin European Tourism Management ,12(13),145-147

【25】Tang Shuntie.(1998).Communitificationof Tourist Destination and Community Tourism. Geographical Research,17(2),145-149

【26】Vander DuimV R. \& Caalders J.(2008).TourismChains and Pro- poor TourismDevelopment:An A ctor-networkAnalysis of a Pilot Project in Costa Rica.Current Issuesin Tourism,11(2),109- 125.

【27】William s.(2001).Norman, Small towns and villages appeal to us travelers.Fairfield county businessjournal ,17(1),13-21.

【28】Wang Y R.(2016).The Business Strategyof Tea Tourism Industry in the Market Orientation.Tea in Fujian,38(5),141-142.

【29】ZhouXinhong.(2002).ConcerningfortheBasic Elementsin“Tourism-basedPoverty Elimination". Tourism Tribune,17(1),17-21.

【30】Zhao Yan.(2016).The Development Path of Rural Ecological Tourism Projections under the Operation of BOT Model- Taking Chongqing as an Example.Chinese Journal of Agricultural 
International Journal of Social Science and Economic Research

ISSN: 2455-8834

Volume:06, Issue:03 "March 2021"

Resources and Regional Planning,37(10),39-45

【31】Zapata M J.,Hall C M. \& Lindo P,et al.(2011).Can Community-based TourismCon-tributeTo Development and Poverty Alleviation?Lessons from Nicaragua.Current Issuesin Tourism, 14(8),725- 749 .

【32】Zeng B,Ryan C. (2012).Assisting the poor in China through tourism development Areview of research.Tourism Management. 